Kajian Jurnalisme

ISSN 2549-0559 (cetak) ISSN 2549-1946 (online)

Volume 03 Nomor 01 Tahun 2019

\title{
Wacana Islam Radikal dalam Majalah TEMPO
}

\author{
Muhammad Rifqi Fadil dan Pandan Yudhapramesti \\ Program Studi Jurnalistik, Fakultas Ilmu Komunikasi, Universitas Padjadjaran \\ E-mail: rifqyfadil@gmail.com
}

\begin{abstract}
The term radical is often associated with negative things, although in the Indonesian Language Dictionary (KBBI) the meaning is fundamentally (up to the principle), intense demands for change, and advances in thinking or acting. The mass media also echoed this term. Radical meaning is attached to the world of Islam and terrorism. This study aims to determine the Radical Islamic discourse presented by Tempo in the main report in Tempo July 4-10 2016 on the dimensions of the text, discourse practice, and socio-cultural practice, using the method of critical discourse analysis by Norman Fairclough, who views the relationship between text the micro with the macro community. The results of the study show that in the text dimension, the main report shows that the sources of the news were unbalanced and not comprehensive. In the dimension of discourse practice, Tempo created a discourse on Moderate Islam and then created a Radical Islamic discourse that was described as something dangerous. In the sociocultural dimension, Tempo was first hegemony by the thoughts of Islamic leader Nurcholis Madjid about Islamic discourse. Tempo perpetuates the power of the discourse by publishing the main report of the July 4-10 2016 edition and marginalizing rival discourse, by developing Radical Islamic discourse and making related indicators.
\end{abstract}

Keywords: Tempo, Islam, Radical, Islam Radical, Islam Moderat, Norman Fairclough

\begin{abstract}
Abstrak
Istilah radikal acapkali dikaitkan dengan hal negatif, meski dalam Kamus Besar Bahasa Indonesia (KBBI) radikal bermakna secara mendasar (sampai kepada hal yang prinsip), amat keras menuntut perubahan, serta maju dalam berpikir atau bertindak. Istilah yang dikaitkan dengan hal negatif ini banyak didengungkan oleh media massa. Pemaknaan radikal melekat dengan dunia Islam dan terorisme. Penelitian ini bertujuan untuk mengetahui wacana Islam Radikal yang ditampilkan pada laporan Tempo edisi 4-10 Juli 2016 pada dimensi teks, praktik wacana, dan praktik sosial-budaya, menggunakan metode analisis wacana kritis model Norman Fairclough, yang memandang adanya hubungan antara teks yang mikro dengan masyarakat yang makro. Hasil penelitian menunjukkan pada dimensi teks, pada laporan utama terlihat adanya narasumber pemberitaan yang tidak berimbang dan tidak komprehensif. Pada dimensi praktik wacana, Tempo menciptakan wacana Islam Moderat lalu menciptakan pula wacana Islam Radikal yang digambarkan sebagai sesuatu yang berbahaya. Pada dimensi sosiokultural, Tempo telah terlebih dahulu terhegemoni oleh pemikiran tokoh Islam Nurcholis Madjid soal wacana Islam. Tempo melanggengkan kuasa wacana tersebut dengan menerbitkan laporan utama edisi 4-10 Juli 2016 dan meminggirkan wacana tandingan, dengan membangun wacana Islam Radikal dan membuat indikatorindikator terkait.
\end{abstract}

Kata kunci: Tempo, Islam, Radikal, Islam Radikal, Islam Moderat, Norman Fairclough 
58 | Kajian Jurnalisme

ISSN 2549-0559 (cetak) ISSN 2549-1946 (online)

Volume 03 Nomor 01 Tahun 2019

\section{Pendahuluan}

Istilah radikal acapkali didengungkan oleh media massa dewasa ini. Pemaknaan radikal acapkali menjadi suatu keniscayaan dengan hal-hal negatif. Pemaknaan radikal dewasa ini juga melekat dengan dunia Islam dan terorisme. Islam dan radikal seolah menjadi keniscayaan timbulnya terorisme. Salah satu media massa yang menyangkutpautkan istilah radikal dengan terorisme adalah Majalah Berita Mingguan (MBM) TEMPO.

Dalam Kamus Besar Bahasa Indonesia (KBBI), kata radikal dan terorisme memiliki makna dasarnya masing-masing. Kata radikal bermakna secara mendasar (sampai kepada hal yang prinsip), amat keras menuntut perubahan (undang-undang, pemerintahan), serta maju dalam berpikir atau bertindak. Sementara terorisme menurut KBBI adalah penggunaan kekerasan untuk menimbulkan ketakutan dalam usaha mencapai tujuan (terutama tujuan politik); praktik tindakan teror. Ditilik secara harafiah, dua kata ini dapat dikatakan tak berkonotasi negatif.

MBM TEMPO edisi 4-10 Juli 2016, dalam laporan utamanya yang berjudul Islam Jalan Damai, tercatat 8 kali TEMPO menggunakan istilah radikal terkait dengan Islam, terorisme, fundamentalisme, dan intoleransi. Dalam laporan utama yang terdiri dari tiga berita utama tersebut, secara eksplisit TEMPO 2 kali mengaitkan istilah radikal dengan terorisme.

Pemberitaan ini berawal dari pernyataan Badan Nasional Penanggulangan Terorisme (BNPT) yang menyebutkan setidaknya 19 pondok pesantren terindikasi mengajarkan radikalisme. Pondok "keras" tersebut, menurut BNPT sebagaimana dikutip TEMPO dalam pemberitaan ini, terdapat di Cilacap, Lamongan, Lombok Utara, Ambon, Makasar, Poso, Jakarta, Cirebon, Ciamis, Solo, Serang, dan Aceh. Menurut TEMPO, hal tersebut cukup mencemaskan di tengah berkembangnya ancaman terorisme dan radikalisme yang menghantui negeri ini.

Dalam pemberitaan ini, TEMPO melaporkan bahwa organisasi masyarakat berlatar belakang Islam dianggap paling lantang menyuarakan gagasan radikalisme. Menurut laporannya, aparat negara menjadi aktor dalam pembubaran ebebasan berekspresi. Sepanjang tahun 2015 terjadi 119 kasus pelanggaran kebebasan beragama dan berkeyakinan, naik 23\% dari tahun sebelumnya.

Hakikat dasar memberitakan sesuatu adalah melaporkan suatu peristiwa apa adanya. Wartawan harus menyajikan fakta dalam pemberitaannya, sebagaimana ia saksikan sendiri atau disaksikan oleh orang lain. Tidak ada fakta yang disembunyikan, ditambah, atau dikurangi. Fakta harus disajikan secara lengkap, akurat, dan relevan.

Pihak independen dibutuhkan untuk memberi pandangan yang lebih luas dan berimbang dalam pemberitaan sesuai asas dasar jurnalisme. Bill Kovach dan Tom Rosenstiel (Kovach \& Rosenstiel, 2003) membuat riset yang komprehensif terhadap apa yang sesungguhnya dikerjakan oleh para wartawan yang tertuang dalam buku Sembilan Elemen Jurnalisme.

Menarik jika MBM TEMPO mengeluarkan laporan utama yang hanya terdiri dari tiga buah berita pokok. Umumnya, TEMPO memuat setidaknya lebih dari 5 hingga 6 buah berita pokok. Menjadi pertanyaan ialah motif TEMPO menerbitkan topik bahasan tersebut menjadi 
laporan utama dengan butir berita yang sangat sedikit. Juga mempertimbangkan asas keberimbangan dalam hal memberikan ruang kepada objek wacana Islam Radikal oleh TEMPO sendiri yang tidak komprehensif.

Dari total 11 narasumber yang digunakan TEMPO dalam seluruh pemberitaan laporan utama yang memunculkan wacana tersebut, 9 diantaranya ialah narasumber yang pro dengan wacana yang diusung, sementara 2 diantaranya netral. Sementara merujuk pada Kovach dan Rosenthiel (2006;6), Jurnalisme harus menyiarkan berita komprehensif dan proporsional, termasuk dalam konteks penyiarannya ialah narasumber yang dipilih.

\section{Metode}

Peneliti tertarik untuk meneliti lebih jauh apa yang dimaksud oleh TEMPO dengan pemunculan dan penekanan wacana Islam Radikal dalam laporan utama edisi tersebut. Indikasi bias makna dalam pewacana laporan khusus tersebut, jika menilik arti secara harafiah di dalam KBBI menjadi sisi ketertarikan peneliti untuk menjabarkan lebih luas mengenai wacana tersebut. Untuk itu peneliti merasa tertarik untuk meneliti hal tersebut dilihat dari paradigma kritis guna menemukan benang merah mengapa wacana tersebut dapat diproduksi dan dikembangkan terkait dengan faktor praktik teks tersebut serta dampak sosiokulturalnya.

Atas pertanyaan tersebut, maka peneliti ingin menggali lebih dalam mengapa TEMPO memproduksi wacana Islam Radikal dalam pemberitaan terkait. Maka peneliti mengkaji maksud pemaknaan dari penekanan lingustik terhadap praktik wacana dan dampak sosiokultural terkait wacana yang dikembangkan tersebut. Dengan menggunakan wacana, seseorang tidak hanya mampu mengarahkan, tetapi juga mampu membatasi perhatian dan merekayasa batin khalayak sasaran. Dengan demikian, tindakan berbahasa dapat memengaruhi, menguasai, menundukkan, dan bahkan menjinakkan manusia lain (Burke, 1966: $31)$.

Untuk hal tersebut, "pisau bedah" analisis Norman Fairclough dianggap paling tepat guna memenuhi kebutuhan jawaban yang ingin diteliti. Analisis Fairclough membangun model yang mengintegrasikan secara bersama-sama analisis wacana yang didasarkan pada linguistik dan pemikiran sosial dan politik, dan secara umum diintegrasikan pada perubahan sosial (Eriyanto, 2002: 285-286). Dengan menggunakan AWK Norman Fairclogh, peneliti ingin membedah pertanyaan-pertanyaan tersebut untuk mendapatkan gambaran wacana Islam Radikal yang dimaksud oleh TEMPO edisi 4-10 Juli 2016. Dalam AWK, teks dibangun dari pilihan-pilihan sistem yang tersedia (kosa kata, tata bahasa, dan lain-lain) secara spesifik dan mengandung makna ideologis. Jika analisis wacana menekankan kepada pemilihan kosakata dalam membentuk kategorisasi, maka analisis wacana kritis bertujuan menunjukkan hubungan antara teks dan proses produksi dengan praktek sosial yang lebih luas di mana mereka berada.

\section{Hasil dan Pembahasan}

TEMPO edisi 4-10 Juli 2016 menurunkan laporan utama bertajuk Islam jalan Damai, terdiri dari 3 berita utama. Berita pertama berjudul Penyemai Sejuk Ayat-ayat Tuhan, halaman 34, paragraf ke-10 tertulis “Menurut Kepala BNPT Komisaris Jenderal Tito Karnavian, ajaran 
60 | Kajian Jurnalisme

ISSN 2549-0559 (cetak) ISSN 2549-1946 (online)

Volume 03 Nomor 01 Tahun 2019

radikalisme dan terorisme tumbuh subur melalui jejaring media sosial. " Pada paragraf ke-11, tercatat TEMPO mengaitkan istilah radikal dengan Islam dan intoleransi dalam satu konteks topik bahasan: "Sejumlah peristiwa kekerasan berlatar belakang intoleransi meluas di Indonesia dalam sekian tahun belakangan. Pelakunya kebanyakan menyuarakan gagasan radikalisme agama oleh organisasi kemasyarakatan atau kelompok berlatar belakang Islam." Paragraf ke-12 tertulis "Di tengah berkembangnya radikalisme dan terorisme, kehadiran Pesantren Al-Mahrusiyah menjadi penting." Sisanya, TEMPO dalam edisi ini menggunakan istilah-istilah tersebut secara terpisah tetapi dalam konteks masih dalam satu konteks yang sama.

Dalam laporan utamanya tersebut, TEMPO menuliskan nama sejumlah pondok pesantren beserta kurikulum pendidikannya, diantaranya Pondok Pesantren Al-Mahrusiyah Lirboyo di Kediri, Jawa Timur, Pondok Pesantren Nurul Ummahat di Prenggan, Kotagede, Yogyakarta, serta Pondok Pesantren Kebon Jambu di Cirebon, Jawa Barat. Bahkan yang terakhir, disebut TEMPO sebagai pesantren pertama yang dipimpin oleh seorang perempuan dan menjadi simbol pembaruan Islam dalam isu gender. Pesantren tersebut dipimpin oleh Nyai Hajah Masriyah Amva.

Jika membaca isi pemberitaan tersebut, maka dapat dilihat narasumber yang digunakan dalam pemberitaan tersebut seluruhnya mendukung wacana yang dibingkai, hampir tidak ada pihak netral yang dijadikan narasumber dalam pemberitaan tersebut. Contoh terkait misalnya: "Gus Reza (Kiai Haji Reza Ahmad Zaid, red) dari Lirboyo juga cemas terhadap tumbuhnya paham terorisme dan radikalisme ke dalam pesantren. Menurut dia, radikalisme tumbuh karena lemahnya ajaran kemajemukan. Menjawab itu, Irwan (Irwan Masduqi, Pemimpin Pesantren Assalafiyah Mlangi, Nogotirto, Gamping, Sleman, Yogyakarta, red) menjelaskan bahwa fundamentalisme ada di semua agama. Terorisme lahir karena ada yang memahami agama hanya secara tekstual. Kondisinya memburuk karena dibalut kepentingan politik, ekonomi, dan sosial. ("Islam Jalan Damai," 2016: 33-38).

Seperti dinyatakan oleh Kovach \& Rosenstiel (Kovach \& Rosenstiel, 2003), pihak independen dibutuhkan untuk memberi pandangan yang lebih luas dan berimbang dalam pemberitaan tersebut sesuai asas dasar jurnalisme. Secara komprehensif, Kovach dan Resenstiel menyebutkan secara komprehensif hal-hal yang harus dilakukan wartawan dalam melakukan pemberitaannya. Hal-hal yang dimaksud Kovach \& Rosenstiel ter Terhadap apa yang sesungguhnya dikerjakan oleh para wartawan yang tertuang dalam buku Sembilan Elemen Jurnalisme. Dalam buku ini disebutkan ada 9 elemen ideal yang dapat dijadikan pedoman bagi wartawan dalam menjalankan tugas jurnalistiknya. Berikut adalah kesembilan elemen jurnalisme yang dikemukakan oleh Bill Kovach dan Tom Rosenstiel (Kovach dan Rosenstiel, 2006:6): 1) Kewajiban pertama jurnalisme adalah pada kebenaran; 2) Loyalitas pertama jurnalisme adalah kepada masyarakat; 3) Intisari jurnalisme adalah disiplin verifikasi; 4) Praktisi jurnalisme harus menjaga independensi terhadap sumber berita; 5) Jurnalisme harus menjadi pemantau kekuasaan; 6) Jurnalisme harus menyediakan forum kritik dan komentar publik; 7) Jurnalisme harus berupaya keras untuk membuat hal yang penting menarik dan relevan; 8) Jurnalisme harus menyiarkan berita komprehensif dan proporsional; 9) Praktisi 
Kajian Jurnalisme

ISSN 2549-0559 (cetak) ISSN 2549-1946 (online)

Volume 03 Nomor 01 Tahun 2019

jurnalisme itu memiliki kewajiban utama terhadap suara hatinya.

Kaitan dengan ketidakberimbangan pemberitaan ini dapat dilihat pada poin ke delapan dalam penjabaran diatas tersebut. Dalam elemen ini jurnalisme harus menjaga berita agar tetap proporsional dan tidak menghilangkan hal-hal yang penting merupakan dasar dari kebenaran. Berikut ialah alur praktik wacana Islam Radikal dalam pemberitaan tersebut:

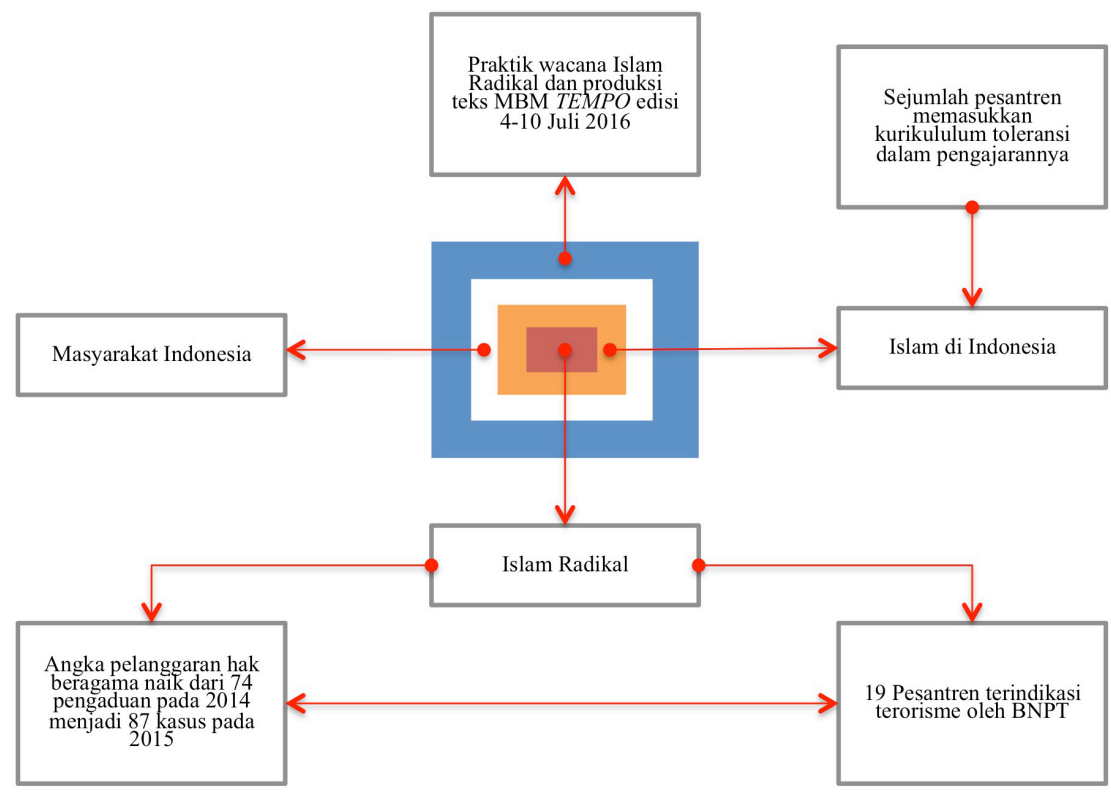

Gambar 1 Alur Praktik Wacana Islam Radikal di MBM TEMPO edisi 4-10 Juli 2016

(Sumber: Hasil Analisis Peneliti)

Menurut teori konflik Dahrendoff (Ritzer, 2012), setiap asosiasi, orang-orang yang berada pada posisi dominan akan berusaha mempertahankan status quo, sementara orangorang yang berada pada posisi sub-ordinat akan berusaha mengadakan perubahan. Menurut Dahrendoof, konflik menyebabkan perubahan dan perkembangan dan pada saat konflik terjadi perubahan yang radikal atau mengakar akan terbentuk.

Konflik keagamaan di Indonesia sudah lazim terjadi. Biasanya, konflik keagamaan berwujud dalam dua jenis aksi, yaitu 1) aksi damai, dan 2) aksi kekerasan. Aksi damai dipahami sebagai setiap tindakan yang dilakukan tanpa kekerasan dalam rangka menanggapi isu-isu keagamaan yang menjadi sumber pertikaian di masyarakat, seperti aksi protes (aksi menolak suatu pandangan atau kebijakan menyangkut isu yang diperselisihkan), aksi dukungan (aksi mendukung suatu pandangan atau kebijakan menyangkut isu yang diperselisihkan), maupun aksi mediasi (tindakan yang dilakukan dalam rangka mendukung upaya penyelesaian konflik yang tengah terjadi). Sementara itu, aksi kekerasan adalah setiap tindakan fisik yang dilakukan dalam rangka menanggapi isu-isu keagamaan yang menjadi sumber pertikaian, yang melibatkan dampak kekerasan baik terhadap orang (berupa kematian, luka, hilang atau mengungsi) maupun harta-benda (berupa kerugian, kerusakan maupun kehilangan) - kendati dampak kekerasan itu tidak mesti selalu nyata. Dalam hal ini, pertarungan wacana merupakan 
62| Kajian Jurnalisme

ISSN 2549-0559 (cetak) ISSN 2549-1946 (online)

Volume 03 Nomor 01 Tahun 2019

bagian dari aksi damai dalam konflik keagamaan.

Dalam konteks wacana Islam Radikal yang dikembangkan TEMPO, terdapat tumbukan wacana Islam Radikal dengan Islam yang dianggap toleran dan perlu dipertahankan. Islam Radikal digambarkan sebagai sesuatu yang muncul dan perlu "ditangkis" dengan Islam yang dianggap toleran.

Isi pemberitaan harus dibuat wajar tanpa dilebih-lebihkan dengan tujuan memenuhi unsur proporsional berita. Menjaga keberimbangan dalam pemberitaan baik dari bahan, isi, serta penyajian merupakan kewajiban berdasarkan penjabaran tersebut. Kata radikal berasal dari kata radix yang dalam bahasa Latin artinya akar. Dalam KBBI dalam jaringan, kata radikal memiliki arti: mendasar (sampai pada hal yang prinsip), sikap politik amat keras menuntut perubahan (undang-undang, pemerintahan), maju dalam berpikir dan bertindak.

Merujuk kata radikal kepada pengertian asalnya, kata radikal merupakan kata yang bersifat netral, tidak condong kepada sesuatu yang bermakna positif atau negatif. Positif atau negatif tergantung dengan pasangan katanya, seperti "Muslim Radikal" yang berarti muslim yang sangat memegang prinsip hidupnya sesuai dengan keyakinannya yakni agama Islam. Dimana baik secara keyakinan, ucapan dan perbuatan semuanya dikembalikan kepada agama Islam sebagai bentuk prinsip hidupnya.

Laporan utama MBM TEMPO edisi 4-10 Juli 2016 hanya terdiri dari tiga buah berita pokok, diluar kebiaasaan TEMPO yang biasanya memuat setidaknya 5 hingga 6 buah berita pokok. Pertanyaan yang muncul adalah apa motif TEMPO menerbitkan topik bahasan tersebut menjadi laporan utama dengan butir berita yang sangat sedikit? Asas keberimbangan dalam hal memberikan ruang kepada objek wacana Islam Radikal oleh TEMPO menjadi tidak komprehensif.

Tabel 1 Narasumber dalam laporan utama TEMPO edisi 4-10 Juli 2016

\begin{tabular}{|c|c|c|c|}
\hline No & Narasumber & Jabatan & $\begin{array}{c}\text { Pro/Kontra } \\
\text { dengan Wacana }\end{array}$ \\
\hline 1 & KH. Reza Ahmad Zahid & $\begin{array}{l}\text { Pimpinan Pondok Pesantren Al-Mahrusiyah, } \\
\text { Lirboyo, Jawa Timur }\end{array}$ & Pro \\
\hline 2 & Komjen. Tito Karnavian & Kepala BNPT & Pro \\
\hline 3 & Hadi Rahman & Anggota Staf Khusus Menteri Agama RI & Pro \\
\hline 4 & KH. Abdul Muhamimin & $\begin{array}{l}\text { Pemimpin Pondok Pesantren Nurul } \\
\text { Ummahat, Kotagede, Yogyakarta }\end{array}$ & Pro \\
\hline 5 & Irwan Masduqi & $\begin{array}{l}\text { Pemimpin Pondok Pesantren Assalafiyah } \\
\text { Mlangi, Sleman, Yogyakarta }\end{array}$ & Pro \\
\hline 6 & Hamzah Sahal & Periset Pondok Pesantren & Pro \\
\hline 7 & Masriyah Amva & $\begin{array}{l}\text { Pemimpin Pondok Pesantren Kebon Jambu, } \\
\text { Cirebon, Jawa Barat }\end{array}$ & Pro \\
\hline 8 & Masruchah & Ketua Komnas Perempuan & Pro \\
\hline 9 & Ahmad Suaedy & Aktivis Wahid Institute & Pro \\
\hline 1 & M. Miftah & $\begin{array}{l}\text { Pengurus Pesantren Benda Kerep, Cirebon, } \\
\text { Jawa Barat }\end{array}$ & Netral \\
\hline 1 & Anom Kusumajati & $\begin{array}{l}\text { Pemimpin Pondok Pesantren Al-Jauhariyah, } \\
\text { Cirebon, Jawa Barat }\end{array}$ & Netral \\
\hline
\end{tabular}

(Sumber: Hasil Analisis Peneliti) 
Kajian Jurnalisme

ISSN 2549-0559 (cetak) ISSN 2549-1946 (online)

Volume 03 Nomor 01 Tahun 2019

Melihat tabel 1 di atas, terlihat komposisi pemilihan narasumber yang dipakai TEMPO dimana 9 diataranya pro terhadap wacana yang diusung, 2 orang netral, dan tidak ada satu orangpun narasumber yang kontra terhadap wacana tersebut. Merujuk pada Kovach dan Rosenthiel (Kovach \& Rosenstiel, 2003) seharusnya praktik jurnalisme harus menyiarkan berita komprehensif dan proporsional, termasuk dalam konteks pemilihan narasumber. Dengan menggunakan wacana, seseorang tidak hanya mampu mengarahkan, tetapi juga mampu membatasi perhatian dan merekayasa batin khalayak sasaran, dengan demikian, tindakan berbahasa dapat memengaruhi, menguasai, menundukkan, dan bahkan menjinakkan manusia lain (Burke, 1966). Analisis Wacanan Kritis memandang teks dibangun dari pilihan sisten yang tersedia (kosa kata, tata bahasa, dan lain-lain) yang secara spesifik mengandung ideologis dan menunjukkan hubungan antara teks, proses produksi, dan praktik sosial yang lebih luas (Eriyanto, 2002). Melalui pendekatan AWK Fairclough, analisis bahasa harus dilakukan secara intertekstual, dimana pengetahuan terhadap suatu konteks akan mempengaruhi pembentukan makna teks oleh teks lain dan antara wartawan dan media menyadari atas kekuasaan yang dimilikinya dapat memengaruhi isi berita. Secara teknis, Fairclough melakukan analisis wacana kritisnya pada aspek dimensi teks, praktik wacana, dan praktik sosikultural.

\section{Wacana Islam Radikal dalam dimensi teks laporan utama MBM TEMPO edisi 4-10 Juli 2016}

Unsur kelayakan sebuah berita diantaranya: 1) berita harus akurat; 2) berita harus lengkap, adil, dan berimbang; 3) berita harus objektif; 4) berita harus ringkas dan jelas; dan 5) berita harus hangat. (Kusumaningrat, 2006).

Akurasi dinilai dari kecermatan terhadap ejaan nama, angka, tanggal, dan usia serta disiplin diri untuk senantiasa melakukan periksa-ulang atau keterangan dan fakta yang ditemui. Akurasi juga berarti benar dalam memberikan kesan umum, benar dalam sudut pandang pemberitaan yang dicapai oleh penyajian detail-detail fakta dan oleh tekanan yang diberikan pada fakta-faktanya. Secara teknis, laporan utama ini sebagian sudah memenuhi unsur akurasi terhadap ejaan nama, angka, tanggal, usia, dsb. Tetapi dalam kesan umum dan sudut pandang pemberitaan, teks ini dapat dikatakan kurang detail penyajiaannya yang berikutnya akan dibahas dalam poin selanjutnya.

Dalam hal sikap adil dan berimbang, seorang wartawan harus melaporkan apa yang sesungguhnya terjadi. Wartawan harus senantiasa berusaha untuk menempatkan setiap fakta atau kumpulan fakta-fakta menurut proporsinya yang wajar, untuk mengaitkannya secara berarti dengan unsur-unsur lain dan untuk membangun segi pentingnya berita secara keseluruhan. TEMPO dalam hal ini menyajikan teks yang tidak berimbang, berat sebelah, dan tidak proporsional. TEMPO tidak memberikan ruang sama sekali terhadap wacana yang dipinggirkannya yakni kelompok yang dianggap Islam Radikal. Teks pemberitaan ini sebagian besar berisi dukungan terhadap wacana dominan yang sejalan dengan TEMPO. Penyudutan wacana tersebut dapat dilihat dari narasumber yang digunakan dalam laporan tersebut. Tampilan teks beberapa sisi menyudutkan wacana yang berseberangan dengan TEMPO seperti penggunaan kata mencemaskan, mengkhawatirkan, "keras" tanpa diberi ruang "pembelaan" 
64 | Kajian Jurnalisme

ISSN 2549-0559 (cetak) ISSN 2549-1946 (online)

Volume 03 Nomor 01 Tahun 2019

oleh TEMPO. TEMPO tidak memberi ruang kepada lawan wacananya untuk "membela diri" dan hanya menggunakan sudut pandang wacana yang sejalan dengan TEMPO sehingga berita yang ditampilkan justru berat sebelah dan sarat prasangka.

Dalam hal teks ringkas dan jelas, TEMPO menyajikannya dengan kata-kata yang mudah dibaca serta gaya berkisah yang mengalir. Begitu pula dengan unsur waktu, kebaruan, dan selalu hangat, tercermin dalam laporan utama ini. Charnley, sebagaimana dikutip oleh Siregar (Siregar, 1998), peristiwa-peristiwa bersifat tidak kekal, apa yang nanpak hari ni belum tentu benar besok hari. Siregar menambahkan, nilai berita diantaranya pening, aktual, kedekatan, dan manusiawi. Jika dilihat dari keempat nilai berita ini, semuanya terdapat dalam laporan utama TEMPO ini.

Secara umum, teks dalam laporan utama TEMPO ini tidak terperinci dan belum mampu menggambarkan bagaimana wacana yang diusung dan sikap kontradiktif TEMPO dengan wacana yang berseberangan. Secara eksplisit TEMPO memojokkan orang-orang yang dianggap radikal, memojokkan orang yang memiliki tafsir lain yang tidak sejalan dengan pluralisme dan toleransi, namun kurang rinci menjabarkannya dengan rangkaian data.

Apabila ditelisik menurut elemen-elemen jurnalisme Kovach dan Rosenstiel, beritaberita yang tergabung dalam rubrik laporan utama TEMPO edisi 4-10 Juli 2019 ini, penjabarannya adalah sebagai berikut:

(1) Konteks kebenaran dalam laporan utama ini tidaklah mutlak (elemen jurnalisme pertama, kewajiban utama jurnalisme adalah pada kebenaran). TEMPO menyajikan praktik pengajaran toleransi di beberapa pesantren sebagai upaya kontra terhadap pemahaman Islam Radikal, ada penonjolan wacana tanpa ada penjelasan lebih lanjut.

(2) Melalui tulisan-tulisannya di rubrik laporan utamanya, TEMPO telah berpihak kepada masyarakat, artinya elemen kedua dari Kovach dan Rosenstiel sudah terpenuhi, loyalitas pertama jurnalisme adalah kepada warga/masyarakat. Salah satu unsur terpenting ialah kesetiaan kepada masyarakat, keberpihakan dari pemberitaan mestilah untuk kepentingan masyarakat umum. Melalui laporan utama ini, TEMPO menunjukkan loyalitasnya terhadap masyarakat dengan membuat laporan utama berkaitan dengan praktik toleransi dan keberagaman di pondok pesantren sebagai upaya kontra terhadap wacana Islam Radikal. Bahwa menurut TEMPO, Islam Radikal akan berbahaya bagi keutuhan kehidupan kemajemukan bangsa Indonesia.

(3) Intisari jurnalisme adalah disiplin Verifikasi. Verifikasi merupakan hal yang sangat penting bagi wartawan dan merupakan salah satu komponen penting dalam jurnalisme. Kebenaran sebuah berita yang layak untuk diterbitkan harus terlebih dahulu melalui proses verifikasi. Elemen ini dapat menguatkan kredibilitas tulisan wartawan di mata khalayak pembaca. Dalam laporan utamanya, TEMPO telah melakukan verifikasi dengan mengacu kepada data dari Badan Nasional Penanggulangan Terorisme (BNPT), lalu diskusi dengan beberapa narasumber ahli tentang isu terkait. Selain itu TEMPO juga melakukan eksekusi ke beberapa 
pesantren di Indoenesia, khususnya pulau di Jawa yag menerapkan pengajaran toleransi. Sejumlah sumber dari beberapa literatur juga disertakan oleh TEMPO untuk melengkapi tulisannya. Dalam Liputan Utama ini TEMPO hanya memaparkan tiga berita terkait. Secara garis besar berita tersebut adalah hasil yang diperoleh dari BNPT dan beberapa tokoh pesantren yang menerapkan toleransi dalam pengajarannya. Namun TEMPO sendiri tidak mengambil sudut pandang dari wacana yang berseberangan yakni pihak Islam Radikal, pondok pesantren yang dianggap radikal, serta narasumber yang netral. Oleh karenanya, TEMPO belum memenuhi unsur disiplin verifikasi dalam pemberitaan ini.

(4) Wartawan harus tetap independen dari pihak yang mereka liput, dengan begitu dedikasi wartawan dalam menyuarakan suara dari pihak yang cenderung tidak di dengar berjalan dengan baik. Wartawan dan narasumber harus memiliki jarak, agar mengurangi resiko bahwa hasil liputan lebih dipengaruhi oleh pihak yang berkepentingan daripada dedikasi wartawan terhadap kepentingan publik. Sayangnya, TEMPO dalam hal ini tidak independen dari pihak yang mereka liput. Dalam pemberitaannya bahkan tidak ada ruang bagi lawan wacana yang didukung TEMPO. Dalam laporan utama ini, TEMPO mendukung wacana Islam Moderat, namun tidak memberi ruang bicara kepada wacana yang kontra yakni Islam Radikal.

(5) Wartawan harus bertindak sebagai pemantau independen terhadap kekuasaan. Pada elemen ini, wartawan dan media dituntut menjadi pengawas pemerintah dan menginformasikan berbagai hal yang tidak diketahui khalayak. Praktik belajar mengajar di pondok pesantren dengan memasukkan kurikulum toleransi dan keberagaman seperti yang digambarkan dalam laporan utama ini memberi informasi sisi lain tentang pondok pesantren dan dunia Islam secara umumnya. Tetapi, di sini TEMPO justru sejalan dengan pemerintah dalam pandangannya terhadap wacana Islam Radikal, dan menyepakati simplifikasi makna radikalisme yang dirilis oleh pemerintah tanpa membedah hal tersebut lebih dalam.

(6) Jurnalisme harus menghadirkan sebuah forum untuk kritik dan komentar public. Proses berjalannya penelitian ini merupakan bukti bahwa jurnalisme mesti menghadirkan forum untuk kritik, dan TEMPO membuat hal tersebut muncul dan dapat dilaksanakan oleh peneliti.

(7) Wartawan Harus Membuat Hal yang Penting Menjadi Menarik dan Relevan. TEMPO menitikberatkan pada pentingnya pengajaran soal toleransi dan keberagaman dalam kehidupan beragama, dalam konteks laporan utama ini ditujukan kepada penganut agama Islam utamanya. Oleh karenanya, TEMPO menyajikan uniknya sistem pengajaran di beberapa pondok pesantren dengan gaya berkisah, serta hal tersebut dikemas sedemikian rupa agar tetap relevan dengan inti pesan yang ingin disampaikan.

(8) Wartawan Harus Menjaga Berita dengan Proporsional dan Menjadikannya Komprehensif Dalam elemen ini ditekankan bahwa kunci akurasi sebuah berita 
66 | Kajian Jurnalisme

ISSN 2549-0559 (cetak) ISSN 2549-1946 (online)

Volume 03 Nomor 01 Tahun 2019

adalah proporsional dan komprehensivitas. Hal ini berarti, sebuah berita tidak boleh hanya memuat pernyataan dari satu pihak saja, tetapi semua pihak yang terlibat juga harus disertakan. Dalam konteks ini TEMPO tidak menyajikannya secara komprehensif dan porporsional. Hanya narasumber yang sesuai dengan wacana yang diusung TEMPO yang diberikan ruang dalam laporan utama ini. Dari total 11 narasumber yang digunakan TEMPO dalam seluruh pemberitaan laporan utama yang memunculkan wacana tersebut, 9 diantaranya ialah narasumber yang pro dengan wacana yang diusung, sementara hanya 2 diantaranya netral, dan bahkan tidak ada narasumber dari pihak yang berseberangan.

(9) Wartawan Punya Kewajiban Terhadap Nurani. Laporan utama ini adalah sebagai bentuk tanggung jawab sosial TEMPO kepada masyarakat. TEMPO menganggap kehidupan beragama yang toleran perlu dipraktikkan dan Islam Radikal sebagai bahaya bagi kehidupan masyarakat Indonesia. Warga juga memiliki hak dan tanggung jawab dalam hal-hal yang terkait dengan berita

Di era digital ini, warga dipandang dapat melakukan kegiatan jurnalistik tanpa harus menjadi jurnalis untuk merekam sebuah peristiwa baik dalam bentuk tulisan maupun dalam bentuk media eletronik. Namun, pada laporan utama ini, tidak ada informasi dari warga yang dicantumkan dalam tulisan untuk melengkapi data. Kebanyakan sumber yang digunakan oleh TEMPO berasal dari data penelitian narasumber yang sesuai dengan wacana terkait.

\section{Wacana Islam Radikal dalam dimensi praktik wacana laporan utama MBM TEMPO edisi 4-10 Juli 2016}

Dalam pandangan kritis, berita adalah hasil dari pertarungan wacana antara berbagai kekuatan dalam masyarakat yang selalu melibatkan pandangan dan ideologi wartawan atau media. Bagaimana realitas itu dijadikan berita sangat tergantung dengan bagaimana pertarungan wacana tersebut terjadi, Hall (Eriyanto, 2011) menyatakan bahwa media massa pada dasarnya tidak mereproduksi melainkan menentukan realitas itu sendiri. Wartawan di sini bukan hanya pelapor, karena ia menjadi partisipan dalam keragaman subjektivitas publik. Wartawan memproduksi berita bukan hanya sebagai penjelas, tetapi membentuk realitas sesuai dengan kepentingan kelompoknya. Wartawan mempunyai nilai-nilai tertentu yang hendak dia perjuangkan yang berpengaruh besar dalam isi pemberitaan.

TEMPO sebagai sebuah media bersifat pro-pluralisme dan mendukung keberagaman memperlihatkan realitas apa yang sedang dibentuk dengan menciptakan realitas Islam yang toleran kemudian diistilahkan dengan Islam Moderat dan menciptakan pula Islam Radikal yang kemudian ditampikan sebagai sesuatu yang berbahaya (Sunudyantoro, wawancara, 5 November 2016). Simplifikasi kategori tersebut merupakan perwujudan bahwa media massa pada dasarnya tidak mereproduksi melainkan menentukan realitas itu sendiri. Sunudyantoro menambahkan bahwa dalam produksi teks, redaksi TEMPO merasa penting untuk skeptis tentang Islam damai, Islam yang bisa menerima perbedaan dan terbuka. Dalam hal ini TEMPO kemudian menciptakan realitas tentang Islam yang dianggap benar oleh TEMPO kemudian mengerdilkan wacana tandingannya yakni Islam Radikal dengan indikator-indikator yang 
diproduksi pula oleh TEMPO. Ciri utama wacana ialah kemampuannya untuk menjadi suatu himpunan wacana yang berfungsi membentuk dan melestarikan hubungan-hubungan kekuasaan dalam masyarakat (Eriyanto, 2011). Konsekuensi dari wacana dominan ialah dapat memberikan arahan dan pandangan bagaimana suatu objek harus dibaca dan dipahami. Tetapi pula pandangan yang lebih luas menjadi terhalang karena ia memberikan pilihan yang tersedia dan siap pakai.

Dalam dimensi produksi teks, TEMPO memproduksi wacana melalui definisi sebagai Islam yang teduh, sejuk, damai, merangkul, dsb. TEMPO memberi arahan bagaimana objek (Islam), harus dipandang seperti apa. Batasan arahan yang dibentuk dalam produksi dan konsumsi teks menyebabkan wacana lain yang tidak dominan menjadi terpinggirkan. Apa yang ditumpahkan di dalam teks dengan kata-kata seperti mengkhawatirkan, mencemaskan, keras, dan sebagainya, merupakan praktik peminggiran wacana selain Islam toleran yang dibuat TEMPO. Islam Radikal dijadikan sebagai wacana tandingan dengan Islam Moderat menurut TEMPO realitasnya dipinggirkan dan disimplifikasi pula dengan indikator-indikator yang dibuat oleh TEMPO (Sunudyantoro, wawancara, 5 November 2016).

Makna diproduksi melalui proses aktif dan dinamis baik dari teks dan konsumen (Eriyanto, 2011). Ideologi bekerja melalui penempatan sesuatu dalam satu bagian tertentu dalam hubungannya dengan sistem tata nilai dalam masyarakat melalui proses pemaknaan, dalam hal ini, TEMPO ialah pembaca teks, Islam ialah sebuah teks, dan kemudian TEMPO menempatkan bagian-bagian tersebut melalui hasil pemaknaan teks yang dikonsumsi.

Ideologi merupakan sistem representasi yang menyamarkan hubungan-hubungan yang sesungguhnya satu sama lain dalam masyarakat dengan cara mengonstruksi hubunganhubungan imajiner antara orang-orang dan antara mereka sendiri dan formasi sosial (Althusser dalam Jorgensen \& Phillips, 2010: 28). Sifat TEMPO yang "mengimani" pluralisme, keberagaman, dan inklusifitas pada praktik wacana melalui laporan utama edisi 4-10 Juli 2016 telah mengonstruksi sebuah formasi sosial dalam masyarakat Islam Indonesia dengan membagi praktik Islam menjadi Islam yang benar dan Islam yang salah (menurut versi TEMPO). Setidaknya TEMPO menuliskan bahwa mayoritas Islam di Indonesia - termasuk kampus seperti UIN, menolak gerakan radikalisme dalam Islam (Sunudyantoro, wawancara, 5 November 2016).

Penerimaan kelompok yang didominasi kelompok dominan berlangsung dalam proses damai, tanpa tindak kekerasan (Eriyanto, 2011). Media dianggap sarana kelompok untuk mengukuhkan posisinya dan merendahkan kelompok lain. Dalam hal ini, TEMPO mengukuhkan posisinya dalam upaya mendukung wacana Islam yang toleran, serta menjatuhkan wacana Islam Radikal.

Salah satu kekuatan hegemoni adalah bagaimana ia menciptakan cara berpikir atau wacana tertentu yang dominan, yang dianggap benar, sementara wacana lain dianggap salah. Ada suatu nilai atau konsensus yang dianggap memang benar, sehingga ketika ada cara pandang atau wacana lain dianggap sebagai tidak benar. (Eriyanto, 2011) TEMPO menganggap bahwa yang paling tepat soal praktik beragama Islam untuk masyarakat Indonesia ialah seperti apa yang TEMPO wacanakan, Islam Moderat, yang menjunjung tinggi nilai keberagaman, 
68 | Kajian Jurnalisme

ISSN 2549-0559 (cetak) ISSN 2549-1946 (online)

Volume 03 Nomor 01 Tahun 2019

toleransi, serta inklusivitas. Di sisi lain, TEMPO menganggap bahwa praktik beragama Islam dengan wacana Islam Radikal ialah salah. Bahkan untuk penggunaan istilah "radikal", TEMPO melakukan simplifikasi sehingga hanya satu makna "radikal" yang dapat diterima oleh publik.

"Memang banyak definisi radikal, namun TEMPO menyederhanakan. Kami sampaikan disitu tentang pandangan atau survey tentang ukuran-ukuran yang dbikin oleh sejumlah lembaga itu, diantaranya adalah tidak mau menerima perbedaan dengan kelompok lain. Cara melihat orang yang radikal bagaimana? Caranya adalah lihat dari perbuatannya. Kalau melihat dari pikirannya. Misalnya dia mengatakan orang lain kafir, tetapi selama dia masih berpikir saja belum bertindak ya tidak bisa diukur. Contohnya dalam undangundang terorisme, tentang orang memberontak negara, orang bisa berpikir tentang melawan negara, namun jika masih berpikir saja belum bisa disebut melawan negara, dia hanya punya ide melawan negara. Namun lain cerita jika ia membuat pelatihan dan lainnya." (Sunudyantoro, wawancara 5 November 2016)

TEMPO melakukan penyederhanaan definisi "radikal" berdasarkan ukuran-ukuran tersebut. Alasan utama penyerdehaaan tersebut muncul untuk memudahkan khalayak memahami tampilan berita yang diterbitkan. Hal yang paling mudah dalam mendefinisikan suatu kelompok termasuk radikal atau tidak ialah melalui tindakan yang telah dilakukan.

Dilihat pada tatanan harfiah hingga tatanan wacana, radikal dapat diartikan ke banyak tafsir. Terkait wacana Islam Radikal, menyangkut aliran, pandangan dunia, ideologi keagamaan dan gerakan, masih diperlukan kualifikasi yang pada gilirannya mengungkapkan kompleksitas yang ada. Tipologi "Islam Radikal", atau "Islam Liberal" atau yang lainnya, perlu ada kualifikasi seperti "radikal" tertentu dalam tingkat tertentu (Azra, 2002). TEMPO tidak memberikan porsi wacana Islam Radikal dalam laporan.

Beberapa kali TEMPO menyinggung soal fundamentalisme Islam yang dianggap membawa dampak buruk dalam praktik toleransi, keberagaman, dan inklusivitas, atau dalam kata lain membawa dampak buruk bagi pengaruh yang akan digencarkan oleh TEMPO, yakni Islam yang toleran.

"Misalnya ada pondok Bin Baz. Itu merupakan pondok yang sangat keras sampai mengkafirkan orang diluar kelompok dia. Di solo juga mungkin juga ada pondok yang juga seperti itu, orang yang di luar kelompoknya adalah kafir. Bin Baz sendiri merupakan pondok pesantren yang membangun sejumlah masjid yang membawa pemahaman Wahabi bagi sejumlah orang yang belajar tentang Islam. Pengajaran ini sendiri sebenarnya kurang bisa include dengan culture Indoenesia. Misalnya ada orang yang yasinan, tahlilan, keselamatan 40 hari atau seribu hari itu baginya merupakan perbuatan yang syirik (menyekutukan Allah, red) karena tidak ada gunanya. Kelompok yang kemudian begitu gampang untuk mengkafirkan orang lain, hanya karena misalnya urusan tahlil atau tidak tahlil, baca yasin atau tidak baca yasin. Ukuran perbuatan radikal yang bisa diikuti ya seperti itu, dan itu diikuti oleh lembaga negara BNPT. Kekhawatiran yang timbul adalah pikiran untuk menjadi radikal sudah dibentuk disitu walaupun belum action." (Sunudyantoro, wawancara 5 November 2016)

Dalam mengonsumsi teks sehingga menjadi praktik wacana, TEMPO telah mencap kelompok Wahabi, sebuah kelompok Islam puritan yang kemudian lebih dikenal sebagai Salafi, masuk kepada kategori radikal. Mansur Mangansing mendeskripsikan Wahabi sebagai gerakan

http://jurnal.unpad.ac.id/kajian-jurnalisme 
pemurnian akidah dan pembaruan dalam Islam oleh Muhammad ibn 'Abd al-Wahhâb (17031787 M) (Mangansing, 2008). Gerakannya untuk memurnikan ajaran Islam, khususnya dalam bidang tauhid sebagai ajaran pokok Islam, tidak ingin mengubah ajaran Islam dengan penafsiran baru terhadap wahyu, melainkan membawa misi memberantas unsur-unsur luar dari ajaran Islam, seperti bidah, khurafat, dan takhyul yang masuk ke dalam ajaran Islam. Dengan demikian, ia bermaksud mengajak umat Islam agar kembali kepada ajaran Islam yang murni. Yang dimaksud dengan ajaran Islam yang murni itu ialah sebagaimana yang dianut dan dipraktekkan di zaman nabi, sahabat serta tabiin, yaitu sampai abad ke-3 Hijriah.

Setidaknya, TEMPO menganggap bahwa pikiran untuk menjadi radikal (radikal menurut definisi yang disederhanakan oleh TEMPO) kemungkinan dibentuk di dalam pondok pesantren dengan nafas Salafi. Kalangan salafi dapat dimasukkan ke dalam kelompok radikal setidaknya dalam pemikiran, tetapi, radikalnya mereka tidak menyentuh dimensi pembaharuan atau reformasi baik dalam pemikiran maupun lainnya. Sikap tersebut hanya terbatas pada sikap dan tidak tertuangkan pada tindakan, maka pengikut salafi tidak menimbulkan masalah sosial dalam kaitannya dengan anggota kelompok lain (Turmudi \& Sahbudi, 2005).

Jika ditilik dari indikator radikal sesuai dari yang dikonstruksikan TEMPO yakni: 1) pengerusakkan dan pelarangan tempat ibadah, 2) pengusiran penganut keyakinan lain, dan 3) kekerasan karena perbedaan ideologi dan pilihan politik, pada kenyataannya tidak pernah dilakukan oleh golongan Salafi, setidaknya tidak ada kelompok yang melakukan tindak radikal seperti yang dijabarkan oleh TEMPO atas nama kelompok Salafi, kemudian praktik beragama mereka justru dikonsumsi oleh TEMPO sebagai praktik menuju radikal, maka dalam hal setidaknya dalam praktik konsumsi teks oleh TEMPO sendiri, TEMPO tidak konsisten dalam mengkategorikan kelompok-kelompok sesuai indikator yang TEMPO buat sendiri.

Salah satu kekuatan hegemoni ialah bagaimana ia menciptakan cara berpikir atau wacana tertentu yang dominan, yang dianggap benar, sementara wacana lain dianggap salah. Ada suatu nilai atau konsensus yang dianggap memang benar, sehingga ketika ada cara pandang atau wacana lain dianggap tidak benar (Eriyanto, 2011). Hal ini terjadi dan eksplisit terlihat dalam tidak ajegnya TEMPO dalam mengkategorikan kelompok-kelompok bahkan dengan indikator yang TEMPO buat sendiri. Untuk sisi konsumsi teks, semestinya, jika ditilik dari indikator "radikal" yang diciptakan sendiri, kelompok Wahabi tidak masuk ke dalam kategori radikal. Tetapi karena secara wacana pehamahaman Wahabi bertentangan dengan wacana dominan TEMPO tentang Islam yang menghormati keberagaman, insklusifitas, dan toleransi, sehingga justru Wahabi dilebur ke dalam wacana yang dipinggirkan oleh TEMPO yakni Islam Radikal, dimana akhirnya TEMPO justru tidak ajeg dengan wacana yang ia pinggirkan beserta indikator-indikatornya, sehingga pemaknaan terhadap wacana Islam Radikal yang TEMPO ciptakan tersebut menjadi bias. Kelompok yang mestinya tidak "radikal" sesuai dengan indikator yang diciptakan TEMPO, malah dimasukkan ke dalam kategori radikal.

Wacana yang dimunculkan TEMPO boleh jadi merupakan usaha TEMPO untuk memperlihatkan konflik yang ada diantara wacana-wacana yang dianggap sedang bertarung. Namun tidak menutup kemungkinan - disadari atau tidak, merupakan kontibusi TEMPO dalam 
70| Kajian Jurnalisme

ISSN 2549-0559 (cetak) ISSN 2549-1946 (online)

Volume 03 Nomor 01 Tahun 2019

upaya pengukuhan wacana tertentu, dalam kaitannya hal ini ialah wacana keislaman.

Konflik dipahami melalui suatu pemahaman bahwa masyarakat memiliki dua wajah karena setiap masyarakat kapan saja tunduk pada perubahan, sehingga asumsinya bahwa perubahan sosial ada dimana-mana, selanjutnya masyarakat juga bisa memperlihatkan perpecahan dan konflik pada saat tertentu dan juga memberikan kontribusi bagi disintegrasi dan perubahan, karena masyarakat didasarkan pada paksaan dari beberapa anggotanya atas orang lain (Ritzer, 2012).

Pada akhirnya, TEMPO belum mampu menyajikan berita yang utuh dan komprehensif. Hal ini terlihat dari pemilihan narasumber dan literatur yang tidak proporsional, bahkan menimbulkan ketidakajegan kategorisasi kelompok berdasarkan wacana-wacana yang dipetakan oleh TEMPO. Hal ini dilakukan sebagai upaya TEMPO untuk menanamkan ideologi dan pandangannya kepada masyarakat dengan jalan yang halus.

\section{Wacana Islam Radikal dalam dimensi praktik sosiokulutal laporan utama MBM TEMPO edisi 4-10 Juli 2016}

Pembahasan mengenai Islam sebagai sebuah wacana di Indonesia akan selalu menarik di tiap bagiannya. Oleh karenanya, TEMPO acapkali memproduksi pemberitaan mengenai wacana keislaman guna menarik perhatian khalayaknya. Secara universal, Arismunandar dalam buku Media dan Citra Muslim: Dari Spiritualitas untuk Berperang menuju Spiritualitas untuk Berdialog (Ibrahim, 2005) menyatakan, dalam media massa barat dan tanggapannya terhadap Islam, sejak tahun 1970-an bersifat problematik dan antipatis. Kata Islam dalam media massa barat menurut Arismunandar sering digunakan media massa barat dalam bentuk generalisasi dan simplifikasi. Meski demikian, dalam konteks di Indonesia, Arismunandar menyebutkan pemberitaan Islam dari dalam negeri cenderung tidak terlalu buruk.

Begitu pula dengan cara TEMPO dalam praktik sosiokultural terkait wacana Islam. TEMPO membuat wacana sendiri terkait Islam dan secara halus melakukan upaya hegemoni atas wacana yang dibuatnya. Salah satu dampak konkritnya ialah, simplifikasi dan generalisasi terhadap Islam Radikal, sebuah wacana yang dibangun TEMPO dalam laporan utama edisi 410 Juli 2016 sebagai sebuah wacana yang dikerdilkan. TEMPO mengusung wacana Islam Moderat sebagai Islam yang toleran, menerima keberagaman, inklusif, dam plural. Hingga akhirnya, TEMPO membuat generalisasi bahwa wacana Islam di luar Islam Moderat ialah Islam yang radikal, yang dibentuk sebagai momok berbahaya bagi masyarakat, dengan indikator-indikator yang dibuat TEMPO.

Termin kata radikal sendiri sebenarnya tidak merujuk kepada tafsiran negatif jika ditilik dari Kamus Besar Bahasa Indonesia (KBBI). Arti radikal dalam Kamus Besar Bahasa Indonesia (KBBI) bermakna secara mendasar (sampai kepada hal yang prinsip), amat keras menuntut perubahan (undang-undang, pemerintahan), serta maju dalam berpikir atau bertindak. Kata awal "radikal" yang membentuk istilah "radikalisme" berasal dari bahasa Latin, radix yang berarti "akar". Dengan demikian, "berpikir secara radikal" sama artinya dengan berpikir hingga ke akarakarnya

Simon Tormey dalam International Enyclopedia of Social Sciences (Vol.7, hal 48) 
seperti dikutip oleh Muhammad Nazib Azca dalam majalah MAARIF Institute Edisi Juli 2013 menyatakan: Radikalisme merupakan sebuah konsep yang bersifat kontekstual dan posisional, dalam hal ini kehadirannya merupakan antitesis dari ortodoks atau arus utama (mainstream), baik bersifat sosial, sekuler, saintifik, maupun keagamaan. Menurutnya, radikalisme tidak mengandung seperangkat gagasan dan argumen, melainkan lebih memuat posisi dan ideologi yang mempersoalkan atau menggugat sesuatu (atau segala sesuatu) yang dianggap mapan, diterima, atau menjadi pandangan umum. Dengan demikian menjadi "radikale pada suatu periode bisa jadi bersalin pada posisi "mainstream"e atau ortodoks di era yang lain. Azca menyatakan ditilik dari dua teori mutakhir dalam kajian ilmu sosial dan ilmu politik, yakni kritik ideologi dan analisis wacana (Azca, 2013), radikalisme dipahami sebagai gejala sosial dan politik yang lahir dalam kondisi dislokasi atau krisis yang bersifat permanen dalam masyarakat. Radikalisme pada gilirannya bisa mewujud ke dalam dua varian yakni: radikalisme demokratis-inklusif dan radikalisme intoleran-ekslusif. Radikalisme demokratisinklusif menggunakan logic of inclusion, sedang radikalisme intoleran-ekslufif menggunakan logic of exclusion. Radikalisme demokratis-inklusif menggunakan logika inklusi dan partisipatoris melalui aksi kolektif untuk membuat perubahan atau bernegosiasi secara politik dengan kekuatan-kekuatan dominan dalam masyarakat dan negara. Sementara radikalisme intoleran-ekslusif menggunakan logika penarikan diri dari koeksistensi pada saat menghadapi dislokasi atau krisis.

Ini sejalan dengan penjabaran Azra (2002: 113-114), bahwa menyangkut aliran, pandangan dunia, ideologi keagamaan dan gerakan, masih diperlukan kualifikasi-kualifikasi lain yang pada gilirannya akan mengungkapkan kompleksitas dan kerumitan yang ada. Boleh jadi seseorang atau gerakan Islam tertentu "radikal" hanya pada tingkat wacana, tetapi tidak pada tingkat praksis, atau mungkin hanya dalam bidang keagamaan tetapi tidak dalam bidang politik, misalnya.

Dalam hal ini, Azra mencontohkan organisasi Muhammadiyah yang dapat dikategorikan sebagai radikal sebagai upaya peruabahan menyeluruh terhadap berbagai bentuk kepercayaan dan praktek keislaman yang sudah tidak murni. Tetapi radikal dalam tingkat keagamaan, ideologi, dan pandangan dunia ini tidak diwujudkan dalam tingkat praktis. Sebaliknya, Muhammadiyah menggunakan pendekatan dan cara-cara damai untuk mencapai aktualisasi "radikalisme"e ideologinya tersebut melalui usaha-usaha pendidikan, dakwah, penyantunan sosial, dan lain-lain (Azra, 2002:115).

Upaya TEMPO melakukan simplifikasi "Islam Radikal" dengan mengkategorikan wacana Islam secara umum di Indonesia menjadi dua bagian saja seperti yang dijabarkan oleh Sunudyantoro, yakni Islam Moderat dan Radikal, adalah upaya untuk mewujudkan sebuah konsensus Islam seperti apa yang semestinya benar dan meresap di masyarakat serta menjadi konsensus bersama. Seperti pernyataan Sunudyantoro secara institusional, TEMPO ingin mewujudkan Islam yang toleran, plural, dan inklusif. Bahkan, TEMPO secara praktis menyatakan dukungannya kepada wacana Islam Moderat.

Pernyataan secara institusional tersebut menggambarkan bagaimana sebuah hegemoni bekerja. Ia tampak berjalan melalui suatu proses atau cara kerja yang tampak wajar. Dalam 
72| Kajian Jurnalisme

ISSN 2549-0559 (cetak) ISSN 2549-1946 (online)

Volume 03 Nomor 01 Tahun 2019

proses produksi berita, proses itu terjadi melalui cara yang has, sehingga apa yang terjadi dan diberitakan oleh media tampak sebagai suatu kebenaran, memang begitulah adanya, logis dan bernalar (Eriyanto, 2011: 105). Dalam hal ini bahkan TEMPO secara gamblang mengakui adanya konflik wacana tersebut, dan berusaha mendominasi wacana Islam Moderat dan meminggirkan wacana Islam Radikal.

Konflik dijabarkan oleh Ralf Dahrendorf (Ritzer, 2012: 450) sebagai bagian dari teori sosiologis, dimana masyarakat terdiri dari konflik dan konsensus(kesepakatan). Dahrendoorf meyakini bahwa masyarakat tidak bisa ada tanpa konflik dan konsensus. Tanpa konsensus sebelumnya, konflik tak akan muncul, begitupun konsensus terbentuk karena adanya konflik, termasuk di dalamnya proses pembentukan sebuah wacana. Seseorang bisa saja berada dalam posisi otoritas dalam suatu asosiasi, namun bisa saja berada pada level subordinat pada asosiasi lainnya. Pada intinya, Dahrendoorf berkeyakinan bahwa fungsi mendasar konflik ialah menciptakan perubahan dan perkembangan (Ritzer, 2012 :452). Dalam konflik wacana ini, diharapkan oleh TEMPO akan muncul konsensus umum di masyarakat bagaimana wacana Islam yang benar. Dalam hal ini, konflik wacana yang dipandang TEMPO sebagai sebuah realitas yang nyata, dinyatakan sebagai upaya perubahan sosial sehingga dapat menimbulkan ketundukkan masayarakat terhadap konsesus yang nantinya menjadi konsensus umum. TEMPO memandang wacana Islam Moderat perlu dimenangkan dan wacana Islam Radikal mesti dikalahkan, kemudian terciptalah perubahan seperti apa yang diinginkan TEMPO.

Salah satu bentuk langkah konkritnya ialah dengan pembuatan indicator-indikator radikal seperti apa yang telah dibahas di bagian praktik wacana. Hingga akhirnya TEMPO sendiri justru tidak ajeg dalam mengklasifikasi kelompok yang tidak sepaham dengan wacana yang TEMPO bangun yakni Islam Moderat, namun juga secara indikasi tidak masuk ke dalam indikator-indikator wacana yang hendak dipinggirkan yakni Islam Radikal. TEMPO secara institusional dalam wawancara telah mencap kelompok Wahabi, sebuah kelompok Islam puritan yang kemudian lebih dikenal sebagai Salafi, masuk kepada kategori radikal. Setidaknya, TEMPO menganggap bahwa pikiran untuk menjadi radikal (radikal menurut definisi yang disederhanakan oleh TEMPO) kemungkinan dibentuk di dalam pondok pesantren dengan nafas Salafi.

Kelompok yang kemudian begitu gampang untuk mengkafirkan orang lain, hanya karena misalnya urusan tahlil atau tidak tahlil, baca yasin atau tidak baca yasin. Ukuran perbuatan radikal yang bisa diikuti ya seperti itu, dan itu diikuti oleh lembaga negara BNPT. Kekawatiran yang timbul adalah pikiran untuk menjadi radikal sudah dibentuk disitu walaupun belum action (Sunudyantoro, wawancara 5 November 2016).

Turmudi dan Sihbudi menjelaskan bahwa kalangan salafi dapat dimasukkan ke dalam kelompok radikal setidaknya dalam pemikiran (Turmudi \& Sahbudi, 2005: 169-170). Tetapi, radikalnya mereka tidak menyentuh dimensi pembaharuan atau reformasi baik dalam pemikiran maupun lainnya. Sikap tersebut hanya terbatas pada sikap dan tidak tertuangkan pada tindakan. Maka pengikut salafi tidak menimbulkan masalah sosial dalam kaitannya dengan anggota kelompok lain. Misalnya saja, mereka berbeda pendapat dalam apa yang dilakukan oleh kelompok Islam lain yang menghancurkan tempat yang dianggap maksiat. 
Dalih yang mereka gunakan adalah bahwa penanganan masalah seperti itu harus dilakukan oleh mereka yang punya power sehingga hal tersebut sebenarnya urusan pemerintah. Apa yang perlu dilakukan ialah bersikap setidaknya negatif terhadap masalah maksiat tadi.

Jika ditilik dari indikator radikal sesuai dari yang dikonstruksikan oleh TEMPO dalam laporan utamanya, yakni 1) pengerusakkan dan pelarangan tempat ibadah, 2) pengusiran penganut keyakinan lain, 3) serta kekerasan karena perbedaan ideologi dan pilihan politik, pada kenyataannya tidak pernah dilakukan oleh golongan Salafi, setidaknya tidak ada kelompok yang melakukan tindak radikal seperti yang dijabarkan oleh TEMPO atas nama kelompok Salafi, kemudian praktik beragama mereka justru dikonsumsi oleh TEMPO sebagai praktik menuju radikal, maka TEMPO tidak konsisten dalam mengkategorikan kelompok-kelompok sesuai indikator yang TEMPO buat sendiri.

TEMPO telah terhegemoni dengan wacana Islam yang dikembangkan Nurcholis Madjid, kemudian menjadikannya sebagai wacana Islam yang diusung TEMPO, kemudian berusaha mendominasi wacana tersebut dengan memetakan wacana Islam yang ada di Indonesia menjadi dua bagian yakni Islam Moderat dan Radikal. Nurcholis Madjid (kemudian akrab disapa Cak Nur) salah satunya mengembangkan relativisme beragama yang menurut Cak Nur merupakan suatu prinsip bahwa memaksakan kebenaran yang diyakini terhadap pihak lain dengan cara dan metode apapun adalah salah. Masing-masing pemeluk agama meyakini suatu kebenaran absolut, tapi kebenaran itu tidak mutlak benar karena hanya hasil penafsiran manusia terhadap agamanya.

Jika digambarkan dalam bagan, maka pandangan TEMPO tentang wacana Islam di Indonesia kurang lebih sebagai berikut:

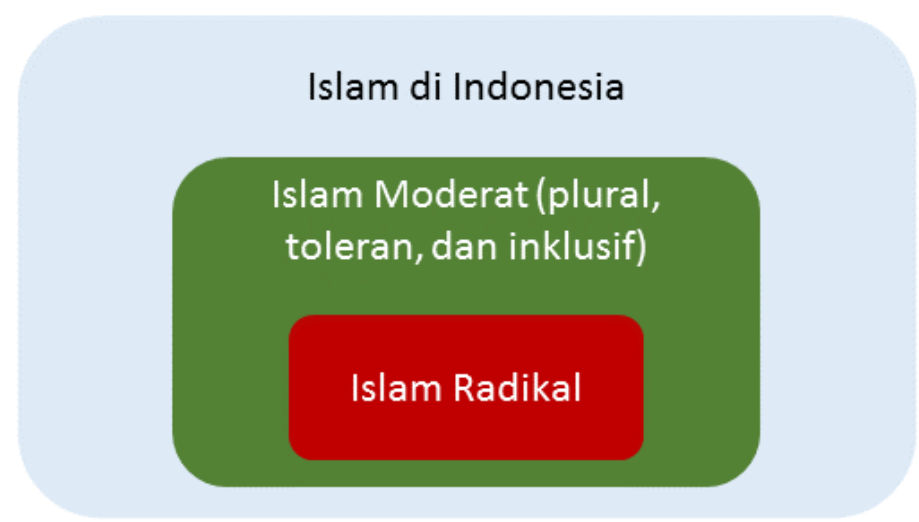

Gambar 2. Pemikiran Cak Nur tentang wacana Islam yang diadopsi TEMPO

(Sumber: Hasil Analisis Peneliti)

Hingga akhirnya, TEMPO membuat indikator-indikator yang membatasi Islam Radikal sebagai "apa yang sudah dilakukan" atau ranah praktis, tetapi secara institusional mengakui eksistensi keberadaan kelompok yang tidak sepaham dengan Islam Moderat, namun tidak masuk ke dalam kelompok Islam Radikal sebagaimana indikator-indikator yang mereka buat. Namun pada teks yang diwujudkan dalam berita, kelompok-kelompok Islam yang tidak berada di keduanya tersebut dimasukkan ke dalam golongan Islam Radikal dengan dalih pemikiran 
74 | Kajian Jurnalisme

ISSN 2549-0559 (cetak) ISSN 2549-1946 (online)

Volume 03 Nomor 01 Tahun 2019

kelompok tersebut mirip dengan apa yang ada di dalam pemikiran kelompok Islam Radikal, meskipun tidak masuk ke dalam indikator yang sudah dibuat oleh TEMPO.

Dalam praktiknya, ketidakajegan kategorisasi dengan indikator yang telah dibuat, hingga tidak diberi ruangnya bagi wacana tandingan untuk "berbicara" dalam laporan utama MBM TEMPO edisi 4-10 Juli 2016 merupakan upaya hegemoni TEMPO hingga muncul pemaknaan Islam Radikal yang kemudian menjadi konsensus publik. Dalam praktik sosiokultural, TEMPO telah terlebih dahulu terhegemoni oleh pemikiran Cak Nur soal wacana Islam, kemudian TEMPO melanggengkan kuasa wacana tersebut dengan menerbitkan laporan utama edisi 410 Juli 2016 dan meminggirkan tandingan wacana yang dibuat oleh TEMPO ke dalam satu wacana yakni Islam Radikal dan membuat indikator-indikator terkait. Visi TEMPO secara institusional dan kedekatan terkait Cak Nur dengan redaksi TEMPO seperti yang dijabarkan sebelumnya menjadi faktor mengapa kuasa wacana tersebut terbentuk.

\section{Simpulan}

Berdasarkan hasil penelitan, peneliti mengambil kesimpulan sebagai berikut: 1) Dalam dimensi teks, laoran utama TEMPO menunjukkan kecenderungan keberpihakannya kepada wacana Islam Moderat. TEMPO berusaha menampilkan pertarungan wacana Islam Moderat dengan Islam Radikal yang sedang terjadi di Indonesia. Secara umum TEMPO menyederhanakan klasifikasi penganut agama Islam di Indonesia menjadi dua kubu yakni Islam Moderat dengan Islam Radikal. TEMPO menyederhanakan hal-hal yang berbau Islam Radikal sebagai suatu ancaman dan bahaya.

Ditilik dengan sembilan elemen jurnalisme, TEMPO belum bisa menyajikan berita secara multidimensional dan komprehensif. Porsi pemberitaan dan narasumber yang semuanya berpihak pada wacana yang TEMPO dukung. Tidak ada ruang yang diberikan untuk lawan wacana yang dikembangkan TEMPO dalam laporan utama ini. 2) Dalam dimensi praktik wacana menyatakan bahwa proses produksi, latar belakang wartawan, serta ideologi TEMPO ketika mengonstruksikan bagaimana Islam dipandang sebagai sebuah wacana dalam memproduksi laporan utamanya. TEMPO sebagai sebuah media bersifat pro-pluralisme dan mendukung keberagaman memperlihatkan realitas apa yang sedang dibentuk dengan menciptakan wacana Islam yang toleran (Islam Moderat) dan menciptakan pula Islam Radikal yang kemudian ditampikan sebagai sesuatu yang berbahaya. Simplifikasi kategori tersebut merupakan perwujudan bahwa media massa pada dasarnya tidak mereproduksi melainkan menentukan realitas itu sendiri. Pemilihan narasumber dan literatur yang tidak proporsional membuat TEMPO belum mampu menyajikan berita yang utuh dan komprehensif, bahkan menimbulkan ketidakajegan kategorisasi kelompok berdasarkan wacana-wacana yang dipetakannya. Hal ini tentu dilakukan sebagai upaya TEMPO untuk menanamkan ideologi dan pandangannya kepada masyarakat dengan jalan yang halus. 3) Dalam dimensi sosiokultural, TEMPO membuat wacana sendiri terkait Islam dan secara halus melakukan upaya hegemoni atas wacana yang dibuat. Salah satu dampak konkritnya adalah simplifikasi dan generalisasi terhadap Islam Radikal, sebuah wacana yang dibangun dan dikerdilkan.

TEMPO mengusung wacana Islam Moderat sebagai Islam yang toleran, menerima 
Kajian Jurnalisme

ISSN 2549-0559 (cetak) ISSN 2549-1946 (online)

Volume 03 Nomor 01 Tahun 2019

keberagaman, inklusif, dan plural, hingga menggeneralisasi bahwa wacana Islam di luar Islam Moderat ialah Islam yang radikal, yang dibentuk sebagai momok berbahaya bagi masyarakat, dengan indikator-indikator yang dibuat TEMPO. Upaya TEMPO melakukan simplifikasi Islam Radikal adalah upaya untuk mewujudkan sebuah konsensus Islam seperti apa yang semestinya benar dan meresap di masyarakat serta menjadi konsensus bersama. Dalam praktik sosiokultural, TEMPO telah terlebih dahulu terhegemoni oleh pemikiran Cak Nur soal wacana Islam, kemudian TEMPO melanggengkan kuasa wacana tersebut dengan menerbitkan laporan utama edisi 4-10 Juli 2016 dan meminggirkan tandingan wacana yang dibuat oleh TEMPO ke dalam satu wacana yakni Islam Radikal dan membuat indikator-indikator terkait. Visi TEMPO secara institusional dan kedekatan terkait Cak Nur dengan redaksi TEMPO seperti yang dijabarkan sebelumnya menjadi faktor mengapa kuasa wacana tersebut terbentuk.

\section{Daftar Pustaka}

Azca, M. N. (2013). Yang Muda, Yang Radikal: Refleksi Sosiologis Terhadap Fenomena Radikalisme Kaum Muda Muslim Di Indonesia. Jurnal Maarif, 8(1).

Azra, A. (2002). Konflik Baru Antar Peradaban: Globalisasi, Radikalisme \& Pluralitas. Jakarta: Raja Grafindo Persada.

Burke, K. (1966). Language as Symbolic Action: Essays on Life, Literature, and Method. Berkley \& Los Angeles: University of California Press.

Eriyanto. (2002). Analisis Framing, Konstruksi, Ideologi, dan Politik Media (13th ed.; N. Huda, Ed.). Yogyakarta: LKiS.

Eriyanto. (2011). Analisis Wacana: Pengantar Analisis Teks Media. Yogyakarta: LKiS.

Ibrahim, I. S. (Ed.). (2005). Media dan Citra Muslim: Dari Spiritualitas untuk Berperang menuju Spiritualitas untuk Berdialog. Bandung: Jalasutra.

Islam Jalan Damai. (2016). TEMPO.

Jorgensen, M. W., \& Phillips, L. J. (2010). Analisis Wacana: Teori dan Metode. Yogyakarta: Pustaka Pelajar.

Kovach, B., \& Rosenstiel, T. (2003). Elemen-elemen Jurnalisme: Apa yang Seharusnya Diketahui Wartawan dan yang Diharapkan Publik. Jakarta: PANTAU.

Kusumaningrat, H. (2006). Jurnalistik Teori dan Praktik. Bandung: Remaja Rosdakarya.

Mangansing, M. (2008). Muhammad Ibn 'Abd Al-Wahhab dab Gerakan Wahabi. 5(3), 319328. https://doi.org/https://doi.org/10.24239/jsi.v5i3.181.319-328

Ritzer, G. (2012). Teori Sosiologi: Dari Sosiologi Klasik Sampai Perkembangan Terakhir Postmodern. Yogyakarta: Pustaka Pelajar.

Siregar, A. (1998). Bagaimana Meliput dan Menulis untuk Media Massa. Yogyakarta: LP3Y.

Turmudi, E., \& Sahbudi, R. (2005). Islam dan Radikalisme di Indonesia. Jakarta: LIPI. 